\title{
The "brain-skin connection" in protein misfolding and amyloid deposits: embryological, pathophysiological, and therapeutic common grounds?
}

\author{
Philip P. Foster ${ }^{1,2,3,4 *}$ \\ 1 Division of Pulmonary and Critical Care Medicine, Department of Internal Medicine, University of Texas Medical Branch, Galveston, TX, USA \\ 2 Division of Cognitive and Behavioral Neurology, Department of Neurology, University of Texas Medical Branch, Galveston, TX, USA \\ ${ }^{3}$ Encephalogistics, Inc., Galveston, TX, USA \\ ${ }^{4}$ Brain-Mind Project, Inc., Galveston, TX, USA \\ *Correspondence: ppfoster@utmb.edu
}

\section{A commentary on}

Association of skin with the pathogenesis and treatment of neurodegenerative amyloidosis

by Clos, A. L., Kayed, R., and LasagnaReeves, C. A. (2012). Front. Neur. 3:5. doi: 10.3389/fneur.2012.00005

A brief history of amyloidosis goes back to autopsies of the seventeenth century reporting a waxing substance (Cordier, 2008). Later, in the middle of the nineteenth century, Rudolph Virchow described an "amyloid" (starch, amulon, Greek, amylum, Latin) degeneration and infiltration of the lungs within alveoli and small vessels in a patient who presented with systemic amyloidosis (heart, lungs, liver, and kidneys; Cordier, 2008). What amyloid-related diseases share is a common molecular ternary structure which involves abnormal aggregation of numerous widespread copies of the same protein into well-ordered filamentous $\beta$-sheet rich structures (Friedman, 2011) known as amyloid fibrils of 10-12 nm diameters (Plante-Bordeneuve and Said, 2011). This abnormal accumulation of amyloid oligomers, protofibrils, or fibrils is considered to be one of the major contributor to neurodegeneration and the hallmark of Alzheimer's (AD) and Parkinson's diseases (Arora et al., 2004). A primary cause underlying these accumulations is the folding of polypeptide chains to specific three-dimensional proteins in abnormal ways (Selkoe, 2003). The progressive misfolding of specific proteins into aggregation may lead to cell alteration or death. Aggregated forms share many characteristics. One of them is that amyloid deposits show specific optical behavior such as birefringence on binding dyes (Congo red). The systemic distribu- tion of amyloidoses may produce extracellular deposits in multiple organs (Joachim et al., 1989). In this paper, Clos, Kayed, and Lasagna-Reeves present a novel perspective about the relation of dermis-epidermisbrain and offer a review about amyloid deposits that are central to the strong "brainskin" connection. This connection starts as early as the sharing a joint embryological origin. Common multipotent embryonic progenitor stem cells from the ectoderm on the surface of the post-gastrulation embryo receive specific signaling from their environment that instruct them to commit to a particular differentiation program which will give rise to the nervous system or skin epithelium (Quan and Hassan, 2005; Fuchs, 2007). Clos, Kayed, and Lasagna-Reeves highlight common "brain-skin" pathophysiological disorders such as the role of presenilin 1 (PS-1) for proteolytic processing of the amyloid precursor protein (APP) which is altered in AD; alteration also found in skin cancers (Xia et al., 2001; Kang et al., 2002). They also draw parallels between neurodegenerative disorders of Parkinson's disease (Lewy bodies, $\alpha$-synuclein, melanin) and amyotrophic lateral sclerosis (ALS inclusion bodies) which share common features with skin diseases (Hays et al., 2006). In addition, Clos, Kayed, and Lasagna-Reeves are describing transdermal route-of-entry as an elected administration route for potential medications to patients with neurodegenerative diseases such as Rivastigmine (AD and Parkinson), Rotigotine (Parkinson). A favorable coefficient of partition (physiologically based pharmacokinetics, PBPK; Thrall et al., 2002) to the brain via the skin vector seems promising for potential drugs targeting the brain (Zhao et al., 2011). In PDAPP transgenic mice, the immunization with the 42-amino-acid form of the peptide
(A $\beta 42)$ prevents the development of cerebral $\beta$-amyloid-plaque formation, neuritic dystrophy and astrogliosis (Schenk et al., 1999); the transdermal route has also been successfully used without detrimental side effects such as $\mathrm{T}$ cell infiltration and cerebral microhemorrhage (Nikolic et al., 2007). Occurrence of the systemic deposition of $\beta$-amyloid protein in multiple tissues such as skin or brain infers that the initial amyloid protein may be produced locally in all organs affected or may, as observed in other human amyloidoses, be derived from a common circulating precursor (Joachim et al., 1989). Therefore the transdermal $\beta$-amyloid immunization also directly targeting skin $\beta$-amyloid deposits may further reduce a potential source for amyloid precursors to other organs such as the brain.

\section{REFERENCES}

Arora, A., Ha, C., and Park, C. B. (2004). Inhibition of insulin amyloid formation by small stress molecules. FEBS Lett. 564, 121-125.

Cordier, J. F. (2008). Pulmonary amyloidosis and nonamyloid immunoglobulin deposits. Rev. Mal. Respir $25,743-765$.

Friedman, R. (2011). Aggregation of amyloids in a cellular context: modelling and experiment. Biochem. J. 438, 415-426.

Fuchs, E. (2007). Scratching the surface of skin development. Nature 445, 834-842.

Hays, A. P., Naini, A., He, C. Z., Mitsumoto, H., and Rowland, L. P. (2006). Sporadic amyotrophic lateral sclerosis and breast cancer: hyaline conglomerate inclusions lead to identification of SOD1 mutation. J. Neurol. Sci. 242, 67-69.

Joachim, C. L., Mori, H., and Selkoe, D. J. (1989). Amyloid beta-protein deposition in tissues other than brain in Alzheimer's disease. Nature 341, 226-230.

Kang, D. E., Soriano, S., Xia, X., Eberhart, C. G., De, S. B., Zheng, H., and Koo, E. H. (2002). Presenilin couples the paired phosphorylation of beta-catenin independent of axin: implications for beta-catenin activation in tumorigenesis. Cell 110, 751-762.

Nikolic, W. V., Bai, Y., Obregon, D., Hou, H., Mori, T., Zeng, J., Ehrhart, J., Shytle, R. D., Giunta, B., Morgan, 
D., Town, T., and Tan, J. (2007). Transcutaneous beta-amyloid immunization reduces cerebral betaamyloid deposits without $\mathrm{T}$ cell infiltration and microhemorrhage. Proc. Natl. Acad. Sci. U.S.A. 104, 2507-2512.

Plante-Bordeneuve, V., and Said, G. (2011). Familial amyloid polyneuropathy 1. Lancet Neurol. 10, 1086-1097.

Quan, X. J., and Hassan, B.A. (2005). From skin to nerve: flies, vertebrates and the first helix. Cell. Mol. Life Sci. 62, 2036-2049.

Schenk, D., Barbour, R., Dunn, W., Gordon, G., Grajeda, H., Guido, T., Hu, K., Huang, J., Johnson-Wood, K., Khan, K., Kholodenko, D., Lee, M., Liao, Z., Lieberburg, I., Motter, R., Mutter, L., Soriano, F., Shopp, G., Vasquez, N., Vandevert, C., Walker, S., Wogulis, M., Yednock, T., Games, D., and Seubert, P. (1999). Immunization with amyloid-beta attenuates
Alzheimer-disease-like pathology in the PDAPP mouse. Nature 400, 173-177.

Selkoe, D. J. (2003). Folding proteins in fatal ways. Nature 426, 900-904.

Thrall, K. D., Gies, R. A., Muniz, J., Woodstock, A. D., and Higgins, G. (2002). Route-of-entry and brain tissue partition coefficients for common superfund contaminants. J. Toxicol. Environ. Health Part A 65, 2075-2086.

Xia, X., Qian, S., Soriano, S., Wu, Y., Fletcher, A. M., Wang, X. J., Koo, E. H., Wu, X., and Zheng, H. (2001). Loss of presenilin 1 is associated with enhanced beta-catenin signaling and skin tumorigenesis. Proc. Natl. Acad. Sci. U.S.A. 98, 10863-10868.

Zhao, J.-H., Ji, L., Wang, H., Chen, Z.-Q., Zhang, Y.-T., Liu, Y., and Feng, N.P. (2011). Microemulsion-based novel transdermal delivery system of tetramethylpyrazine: preparation and evaluation in vitro and in vivo. Int. J. Nanomedicine 6, 1611-1619.

Received: 07 March 2012; accepted: 27 March 2012; published online: 23 April 2012.

Citation: Foster PP (2012) The "brain-skin connection" in protein misfolding and amyloid deposits: embryological, pathophysiological, and therapeutic common grounds? Front. Neur. 3:56. doi: 10.3389/fneur.2012.00056

This article was submitted to Frontiers in Dementia, a specialty of Frontiers in Neurology.

Copyright (c) 2012 Foster. This is an open-access article distributed under the terms of the Creative Commons Attribution Non Commercial License, which permits non-commercial use, distribution, and reproduction in other forums, provided the original authors and source are credited. 